\title{
EFFECT OF PRE-TREATMENT AND INOCULANT DURING COMPOSTING OF PALM OIL EMPTY FRUIT BUNGHES
}

\author{
A.Y. Zahrim ${ }^{*, 1,2}$ \\ I.K.T. Yee ${ }^{1}$ \\ E.S.C Thian ${ }^{1}$ \\ S.Y. Heng ${ }^{1}$ \\ J. Janaun ${ }^{1,2}$ \\ K.P. Chong ${ }^{2}$ \\ S.K. Haywood ${ }^{3}$ \\ V. $\operatorname{Tan}^{4}$ \\ T. Asis ${ }^{5}$
}

T.M.T.M.A. Al-Mizi ${ }^{5}$

${ }^{1}$ Chemical Engineering Programme, Faculty of Engineering, Universiti Malaysia Sabah, Jalan UMS, 88400 Kota Kinabalu, Sabah, MALAYSIA

2 Sustainable Palm Oil Research Unit, Universiti Malaysia Sabah, Jalan UMS, 88400 Kota Kinabalu, Sabah, MALAYSIA

${ }^{3}$ School of Engineering, University of Hull, Cottingham Road, Hull, HU6 7RX, UK

${ }^{4}$ Hatake Global Sdn. Bhd., 151, Jalan USJ 12/1, UEP Subang Jaya, 47630, Selangor, MALAYSIA

${ }^{5}$ Prestige Central Management Sdn. Bhd, 77B Jalan SS21/37 Damansara Utama, 47400 Petaling Jaya, Selangor, MALAYSIA

*e-mail: zahrim@ums.edu.my

In this work, untreated empty fruit bunch (EFB) or microwave-assisted $\mathrm{NaOH}$ pretreated EFB with palm oil mill effluent (POME) were composted under mesophilic conditions either in the presence or absence of Bacillus amyloliquefaciens D203 for sixty days. During pretreatment conditions, the EFB was mixed with $1 \%(\mathrm{w} / \mathrm{w})$ sodium hydroxide and then exposed to microwave irradiation. The composting process was evaluated based on the evolution of $\mathrm{pH}$, electrical conductivity, moisture content, organic matter loss, zeta potential and phytotoxicity. The strain Bacillus amyloliquefaciens D203 is not suitable for EFB-POME composting due to lower organic matter loss. The microwaveassisted $\mathrm{NaOH}$ pretreatment contributed to $\sim 15 \%$ more organic matter loss than was found in the untreated sample while its germination index was $>50 \%$.

Keywords: Composting, Empty fruit bunch, Palm oil mill effluent, Microwave pretreatment, Zeta potential, Phytotoxicity

\section{INTRODUCTION}

The palm oil industry produces millions of tonnes of wastes yearly; these include empty fruit bunch (EFB) and palm oil mill effluent (POME). Fresh POME is a highly viscous liquid, brownish in colour which is discharged at a temperature of $80-90^{\circ} \mathrm{C}$. It is extremely poisonous with very low $\mathrm{pH}$ between 3.5 and 4.2, high chemical and biological oxygen demand (COD: 16-100 $\mathrm{g} / \mathrm{L}, \quad \mathrm{BOD} 5, \quad 30{ }^{\circ} \mathrm{C}:$ 10-44 $\left.\mathrm{g} / \mathrm{L}\right)$, high 
suspended solids (SS: 5-54 g/L), and high salt content (Alhaji et al., 2016). Annually, there are 90 million tonnes of renewable biomass accumulated and EFB accounts for approximately $9 \%$ of this (Bari et al., 2010). Composting, an aerobic biological treatment, could simultaneously manage the EFB and POME (Bukhari et al., 2014, Zahrim et al., 2015) and has the potential to be used as a soil conditioner.

EFB is an abundant lignocellulosic biomass with a worldwide annual production. Like other types of lignocellulosic biomass, EFB is mainly composed of lignin, cellulose and hemicelluloses, as well as other minor elements. For the usual lignocellulose complex found in EFB, cellulose maintains the crystalline fibrous structure and it appears to be at the core of the complex. Hemicellulose is located both between the micro- and macrofibrils of cellulose. Meanwhile, lignin, bound in the interfibrous area, provides the structural matrix in which cellulose and hemicellulose is embedded (Harmsen, Huijgen, Lopez and Bakker, 2010). The recalcitrant structure of EFB causes longer composting time to be needed and hence, the composting area required will be larger. In general, the conventional composting process takes 60 - 90 days (Zahrim and Asis, 2010, Zahrim et al., 2015).

Suitable pretreatment has been shown to assist in reducing the time and space required for composting. From previous literature, the combination of microwave and alkali pretreatment was able to remove more lignin with a shorter pretreatment time compared to other pretreatment methods. Binod et al. (2012) compared various types of microwave pretreatment such as microwave-acid, microwave-alkali and combined microwave-acid-alkali, using sugarcane bagasse as the lignocellulosic waste. It was deduced that the maximum lignin removal was attained for microwave$\mathrm{NaOH}$ pretreatment which achieved about 96\% removal (Binod et al., 2012). The microwave-assisted sulphuric acid pretreatment was not able to remove lignin at a very high rate with maximum lignin removal of only $34.5 \%$ (Jung et al., 2013). The lignin molecular architecture, where different non-phenolic phenylpropanoid units form a complex three-dimensional network linked by a variety of ether and carbon-carbon bonds (Ruiz-Duenas and Martinez, 2009), make the EFB resistant to microbial attack. Besides that, addition of the right combination of microorganisms can speed up the composting process by aiding biodegradation of the EFB structure. It was reported there are 27 strains of indigenous microbes from POME anaerobic sludge alone which were found to exhibit cellulolytic and hemicellulolytic activity, which could enhance biodegradation of EFB and shorten the composting process to as little as 40 days (Zainudin et al., 2013). Other than that, inoculation also improves carbon metabolism of microorganisms, which is indicated by the more stable profile of low molecular weight organic acids (LMWOAs) which are consumed by microorganisms as a nutrient source (Lim et al., 2015)

Based on our knowledge and an extensive review of the literature, there are no studies dealing with microwave pretreatment of combination of EFB and POME for the composting process. As a 
A.Y. Zahrim, I.K.T. Yee, E.S.C. Thian, S.Y. Heng, J. Janaun ,K.P. Chong, S.K. Haywood, V. Tan, T. 3 Asis, T.M.T.M.A Al-Mizi

result, microwave-assisted $\mathrm{NaOH}$ pretreatment prior to composting was carried out in this study. Additionally, inoculation of Bacillus amyloliquefaciens D203 was carried out to study the performance of the pretreated compost.

\section{METHODS}

\section{Composting Materials}

EFB and POME were collected from Merotai Composting Plant, Tawau, Sabah palm oil mill. The EFB was cleaned and dried before they were stored at room temperature. The characteristics of the EFB and POME are presented in Table $\mathbf{1}$ and Table 2 respectively.

Table 1. Physio-chemical Properties of EFB of Palm Oil Industry (Kavitha et al., 2013)

\begin{tabular}{lc}
\hline \multicolumn{1}{c}{ Parameters } & EFB \\
\hline $\mathrm{pH}$ & 7.20 \\
Electrical Conductivity & 2.70 \\
$\left(\mathrm{dS} \mathrm{m}^{-1}\right)$ & 45.10 \\
Organic Carbon (\%) & 0.55 \\
Total Nitrogen (\%) & 82.00 \\
C/N ratio & 0.02 \\
Total Phosphorus (\%) & 1.28 \\
Total Potassium (\%) & 210.00 \\
Total Iron (mg kg $\left.{ }^{-1}\right)$ & 71.00 \\
Total Zinc (mg kg $\left.{ }^{-1}\right)$ & 26.00 \\
Total Copper (mg kg-1) & 88.00 \\
Total Manganese & 33.00 \\
Cellulose (\%) & 30.00 \\
Hemicellulose (\%) & 34.00 \\
Lignin (\%) & \\
\hline
\end{tabular}

Table 2. Physio-chemical Properties of Palm Oil Mill Effluent (POME) (Kavitha et al., 2013)

\begin{tabular}{|c|c|}
\hline Parameters & POME \\
\hline Colour & Yellow \\
\hline $\mathrm{pH}$ & 4.70 \\
\hline Electrical Conductivity & 25.20 \\
\hline $\mathrm{BOD}\left(\mathrm{mg} \mathrm{L}^{-1}\right)$ & 25,000 \\
\hline $\operatorname{COD}\left(\mathrm{mg} \mathrm{L}^{-1}\right)$ & 50,000 \\
\hline TDS & 22,000 \\
\hline TSS & 17,000 \\
\hline Nitrate $\left(\mathrm{mg} \mathrm{L}^{-1}\right)$ & 35.00 \\
\hline Total Nitrogen $\left(\mathrm{mg} \mathrm{L}^{-1}\right)$ & 741.00 \\
\hline Total Phosphorus (mg L $\left.{ }^{-1}\right)$ & 176.00 \\
\hline Total Potassium (mg L-1) & 2,277 \\
\hline Total Iron (mg L $\left.{ }^{-1}\right)$ & 46.50 \\
\hline Total Zinc $\left(\mathrm{mg} \mathrm{L}^{-1}\right)$ & 2.30 \\
\hline Total Manganese $\left(\mathrm{mg} \mathrm{L}^{-1}\right)$ & 615.00 \\
\hline Total Copper $\left(\mathrm{mg} \mathrm{L}^{-1}\right)$ & 0.89 \\
\hline Boron (mg L $\left.{ }^{-1}\right)$ & 7.60 \\
\hline Calcium (mg L-1) & 439.00 \\
\hline
\end{tabular}

\section{Co - Composting Trials and Physiochemical Analysis}

The co-composting trials were run in the Chemical Environmental Engineering Laboratory, Universiti Malaysia Sabah. Approximately $40 \mathrm{~g}$ of EFB was mixed with $72.40 \mathrm{~g}$ of POME for every different set of compost. The mixtures were prepared using the following conditions with Set 1 as control:

Set 1: Untreated EFB + POME (control)

Set 2: Untreated EFB + POME + Inoculants Set 3: Pre-treated EFB + POME

Set 4: Pre-treated EFB + POME + Inoculants 
For Set 3 and 4, the EFB was soaked in $1 \% \mathrm{w} / \mathrm{w} \mathrm{NaOH}$ at a solid-liquid ratio of 1:10 (Binod et al., 2012). Microwave pretreatment was carried out in a domestic microwave (Model: ELBA, EMO-A2072(SV)) at a power of approximately $487 \mathrm{~W}$ for an exposure time of 4 minutes (Binod et al., 2012). The output power was determined by measuring the temperature difference and then using the formula below (Gallawa, 2013):

$$
\text { Output power }=\left(T_{2}-T_{1}\right) \times 70
$$

where $T_{1}$ is the initial temperature and $T_{2}$ is the final temperature.

For Set 2 and 4, inoculants were added to POME before composting. Each mixture was carefully homogenized; moisture was adjusted to $70 \%$ (optimum value for composting). The duration of composting was 60 days. The composting experiment was performed in three replicates in vertical plastic bottles (1.5 L) with 1/4 upper part cut off and left uncovered. The addition of POME was carried out on the $0,25^{\text {th }}, 44^{\text {th }}$ and $57^{\text {th }}$ days, when the moisture content of the mixture fell below $60 \%$ and at the same time the mixture was being turned.

The temperature was measured at 5 day intervals. The $\mathrm{pH}$ and conductivity of every set of compost were determined on the aqueous extract of the compost using a $\mathrm{pH}$ meter (Hanna Instrument (Model:HI 98115)) by adding $20 \mathrm{~g}$ of the sample to $100 \mathrm{ml}$ of distilled water, mixing with magnetic stirrer for 20 minutes, allowing the mixture to stand for $24 \mathrm{hrs}$ and then filtering (Zahrim et al., 2007). Moisture content was determined by drying the sample at $105^{\circ} \mathrm{C}$ for $24 \mathrm{~h}$ (Zahrim et al., 2007). Total organic carbon was calculated after calcination in a furnace at $550^{\circ} \mathrm{C}$ for $4 \mathrm{~h}$. Organic matter loss was determined by the equation below (Paredes et al., 2000), (Zahrim et al., 2007):

$$
\begin{aligned}
& \operatorname{OM} \operatorname{loss}(\%) \\
& =100-100 \frac{\left[\operatorname{Ash}_{i}\left(100-A s h_{f}\right)\right]}{\left[\operatorname{Ash}_{f}\left(100-A s h_{i}\right)\right]}
\end{aligned}
$$

Where $A h_{i}$ is the initial level of ash and $\mathrm{Ash}_{\mathrm{f}}$ is the final level.

\section{Zeta Potential Analysis}

The aqueous extract of the compost was used as the sample for zeta potential analysis. Undiluted samples were used and tested using a Malvern-Zetasizer Nano Series model ZS.

\section{Phytotoxicity Test}

To determine the germination index (GI), cabbage seeds were used and soaked in distilled water for 48 hours with the distilled water being changed every 24 hours. 10 cabbage seeds were tested in $5 \mathrm{ml}$ of water-soluble extracts of compost (from 20 $\mathrm{g}$ of sample into $100 \mathrm{ml}$ of distilled water) in petri dishes on a piece of filter paper in a dark cupboard at room temperature for 3 days. Another 10 cabbage seeds were tested in $5 \mathrm{ml}$ distilled water on just a piece of filter paper as the control. Two replicates were made. The number of germinated seeds was counted and the growth of roots was measured using the grid intersection method (Rowell, 1994) after 3 days. The percentage of relative seed germination (RSG), relative root growth (RRG) and germination index $(\mathrm{Gl})$ were calculated according to the following formulae (Miaomiao et al., 2009): 
A.Y. Zahrim, I.K.T. Yee, E.S.C. Thian, S.Y. Heng, J. Janaun ,K.P. Chong, S.K. Haywood, V. Tan, T. 5 Asis, T.M.T.M.A Al-Mizi

$$
\begin{aligned}
& \text { RSG (\%) } \\
& =\frac{\text { number of seeds germinated in sampple extract }}{\text { number of seeds germinated in control }} \times 100 \\
& R R G(\%)=\frac{\text { root length in sample extract }}{\text { root length in control }} \times 100 \\
& G I(\%)=\frac{R S G}{R R G} x 100
\end{aligned}
$$

\section{Statistical Analysis}

The average value and standard deviation of the data were calculated using Microsoft Excel. The standard error was computed and errors bars were determined for the data.

\section{RESULTS AND DISCUSSION}

pH

In this study, the composting process mainly undergoes mesophilic composting at a temperature that varies from $25.9^{\circ} \mathrm{C}$ to $29.2^{\circ} \mathrm{C}$. The changes in $\mathrm{pH}$ of different sets of compost are shown in Figure 1. The initial $\mathrm{pH}$ values for control, untreated EFB + POME + inoculants, pretreated EFB + POME and pretreated $\mathrm{EFB}+\mathrm{POME}+$ inoculants were $6.4,6.5,6.9$ and 6.7 respectively. The $\mathrm{pH}$ changes for control and untreated $\mathrm{EFB}+\mathrm{POME}+$ inoculants exhibited a different pattern from that of pretreated $\mathrm{EFB}+\mathrm{POME}$ and pretreated $\mathrm{EFB}$ + POME + inoculants for the first 20 composting days; for the remaining composting days, similar patterns of $\mathrm{pH}$ change were presented by all 4 sets.

For the first 20 days, the $\mathrm{pH}$ for Sets 1 and 2 increased from $0-10$ days followed by a decrease until 20 days; $\mathrm{pH}$ for set 3 and 4 decreased from 0 - 10 days followed by an increase until 20 days. Generally, the $\mathrm{pH}$ was maintained in the range of $6.4-9.5$. The $\mathrm{pH}$ change is due to the microbial activity (Kananam et al., 2011).

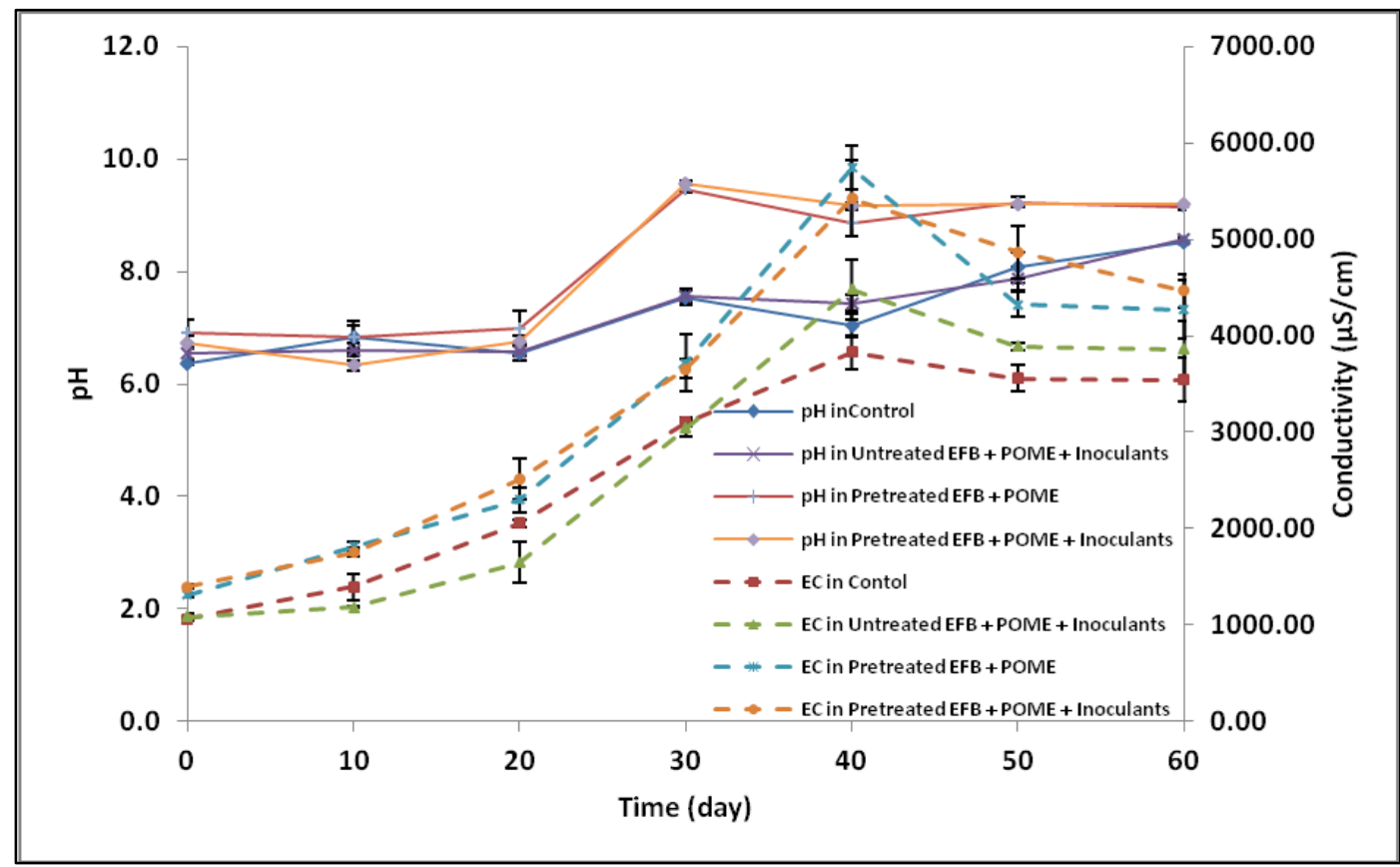

Fig. 1: $\mathrm{pH}$ and electrical conductivity versus time during composting process for untreated and pretreated EFB under different conditions. EFB denotes Empty Fruit Bunch, POME: Palm Oil Mill Effluent 
At the beginning, a slight decrease in pHnoted for pretreated EFB + POME and epretreated $\mathrm{EFB}+\mathrm{POME}+$ inoculants can be explained by the production of organic acids. These result from dissolved $\mathrm{CO}_{2}$ in the medium and by-products from the degradation of easily degradable compounds such as polysaccharides and fats (Yang et al., 2016). On the other hand, the general increase for all sets later can be explained by production of ammonia from the degradation of amines such as proteins and nitrogenous bases which releases bases existing in the organic waste (Ouatmane et al., 2000). According to Arrhenius theory, bases will dissociate in aqeous solution to produce hydroxide. This dissociation of bases in aqueous solution is summarised below.

$\mathrm{NaOH}(\mathrm{aq}) \rightarrow \mathrm{Na}^{+}(\mathrm{aq})+\mathrm{OH}^{-}(\mathrm{aq})$

(Lister and Renshaw, 1991)

$\mathrm{NH}_{4} \mathrm{OH}(\mathrm{aq}) \rightarrow \mathrm{NH}_{4}^{+}(\mathrm{aq})+\mathrm{OH}^{-}(\mathrm{aq})$

(Mittal, 2002)

The increase in $\mathrm{pH}$ is generally thought to be the result of volatilization and microbial decomposition of the organic acids and subsequent release of ammonia through mineralization of organic nitrogen sources (Pan and Sen, 2013).

Microwave irradiation was able to cause the deposition metallic looking silica spheres (Tuval and Gedanken, 2007). From previous studies, there were many silica bodies found on the surface of EFB strands (Baharuddin et al., 2009, Zainudin et al., 2014). Similarly in this study, the inorganic metals, sodium ions from sodium hydroxide might attach to the silica bodies on the lignocellulosic surface to form sodium silicate. The bonds in sodium silicate can be strengthened through application of microwave radiation (Jina et al., 2009). Sodium ions can be attached on fibre through Donnan equilibrium (Stenius, 2011). In addition, the difference in osmotic pressure and electrical potential between the lignocellulosic surface with more negative charge than the bulk solution can result in the movement of $\mathrm{Na}^{+}$to the fibre. The selectively permeable lignocellulosic membrane only allows passage of certain charged ions, such as $\mathrm{Na}^{+}$. $\mathrm{Na}^{+}$attaches to the fibre in an attempt to balance the large negative charge on the fibre (Philipse and Vrij, 2011). During composting, silica and sodium might gradually detached from the EFB structure. Generally, the control and untreated $\mathrm{EFB}+\mathrm{POME}+$ inoculants exhibited lower $\mathrm{pH}$ due to the sole presence of ammonia ions. The elevated $\mathrm{pH}$ of pretreated $\mathrm{EFB}+\mathrm{POME}$ and pretreated $\mathrm{EFB}+\mathrm{POME}+$ inoculants might be due to the combined presence of sodium ions and ammonia produced during composting.

\section{Electrical Conductivity}

The variation of conductivity reveals the extent of mineralization of the organic substrate and the release of the ionic loads into the medium (El Fels et al., 2014). The electrical conductivity changes for the control, untreated $\mathrm{EFB}+\mathrm{POME}+$ inoculants, pretreated $\mathrm{EFB}+\mathrm{POME}$ and pretreated $\mathrm{EFB}+\mathrm{POME}+$ inoculants, presented in Figure 1. The electrical conductivity change for every set of compost exhibited a similar pattern by which electrical conductivity increased initially from 0 day until a maximum value 
A.Y. Zahrim, I.K.T. Yee, E.S.C. Thian, S.Y. Heng, J. Janaun, K.P. Chong, S.K. Haywood, V. Tan, T. 7 Asis, T.M.T.M.A Al-Mizi

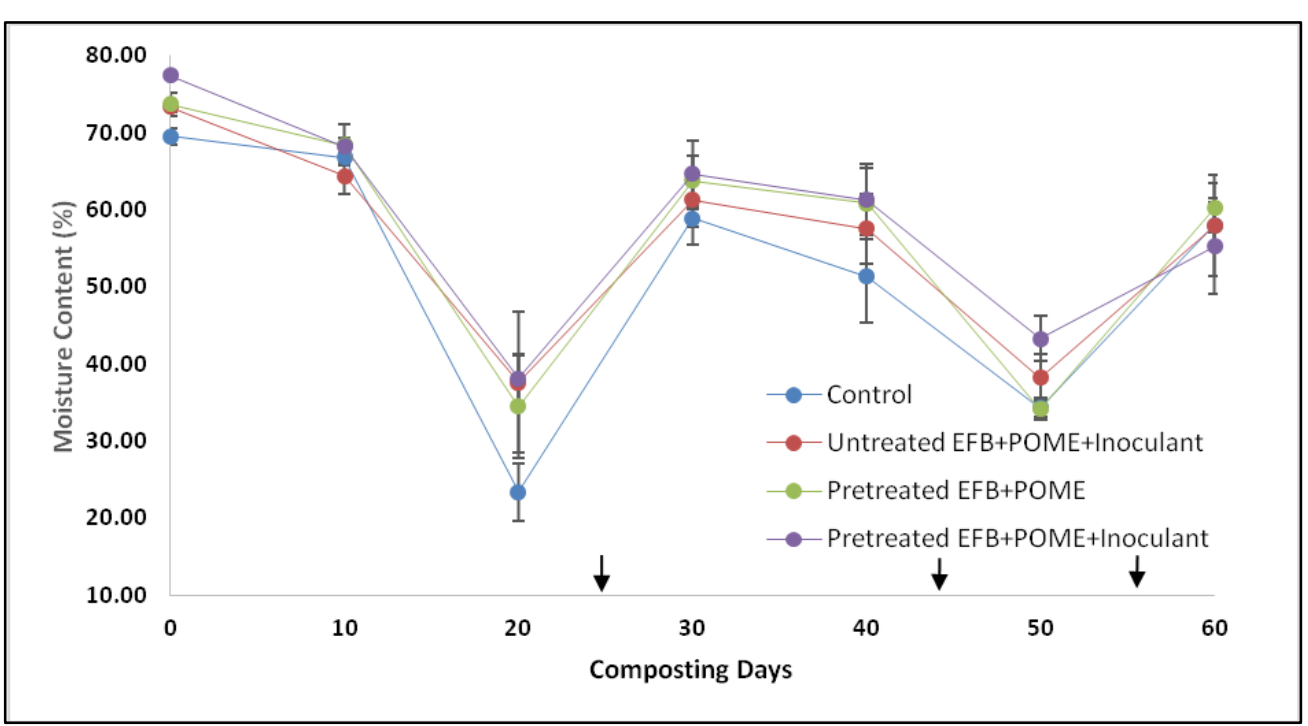

Fig. 2: Moisture Content versus time during composting process for untreated and pretreated EFB under different conditions. EFB denotes Empty Fruit Bunch, POME: Palm Oil Mill Effluent. Arrows indicate the addition of POME on the $25^{\text {th }}, 44^{\text {th }}$, and $57^{\text {th }}$ day.

of 3830, 4483, 5740 and $5423 \mu \mathrm{S} / \mathrm{cm}$ respectively on day 40 , followed by a decrease until the end of the composting process. This increase of electrical conductivity might be caused by the release of mineral salts and ammonium ions from the decomposition of organic matter (Yang et al., 2016). The volatilization of ammonia and precipitation of mineral salts resulted in the decrease of electrical conductivity while the composting process continued (Gao et al., 2010).

For mature and safe compost, the proper value of electrical conductivity should be less than $4000 \mu \mathrm{S} / \mathrm{cm}$ as a value exceeding this value would have an adverse effect on plant growth, resulting in low germination rate and withering of plants (Lin, 2008). The final electrical conductivity values of control and untreated EFB + POME + inoculants were 3540 and 3863 $\mu \mathrm{S} / \mathrm{cm}$ respectively, i.e. less than 4000 $\mu S / \mathrm{cm}$, indicating that they are safe for plants; final electrical conductivity values of pretreated EFB + POME and pretreated EFB
+ POME + inoculants were 4270 and 4463 $\mu \mathrm{S} / \mathrm{cm}$ respectively, which were slightly higher than $4000 \mu \mathrm{S} / \mathrm{cm}$, indicating that the compost is insufficiently stable favourable for plant growth. The higher electrical conductivity for pretreated EFB + POME and pretreated $\mathrm{EFB}+\mathrm{POME}+$ inoculants was due to the combined presence of $\mathrm{Na}^{+}$ ions and silica; Control and untreated EFB + POME + inoculants exhibited lower electrical conductivity due to the sole presence of silica. High electrical conductivity is reported to be unfavourable for plant growth. Thus, compost production via pretreated $E F B+P O M E$ and pretreated $\mathrm{EFB}+\mathrm{POME}+$ inoculants with high electrical conductivity needs to be mixed with other compost with lower electrical conductivity to make it usable (Vakili et al., 2012).

\section{Moisture Content}

The evolution of the moisture content of the different sets of compost is shown in Figure 3. Moisture content is a critical 
factor to optimize the composting system because the microbial dependence on water to support growth could affect the biodegradation of organic matter (Hock et al., 2009). The main mechanism of water removal in this composting process was the evaporation of water $d$ microbial heat generation as well as natural aeration, which dries the compost material continuously. The continuous decrease in the moisture content during composting is an indication of organic matter decomposition (Kulcu and Yaldiz, 2004).

In this study, POME was added to maintain the optimum condition between 50 and $70 \%$ (Ahmad et al., 2011). The initial moisture content for the control (Set 1), untreated EFB with POME and inoculant (Set 2), pretreated EFB with POME (Set 3), and pretreated EFB with POME and inoculant (Set 4 ) are 69.6\%, 73.4\%, 73.68\% and $77.4 \%$ respectively. Each set of compost exhibited the same pattern throughout the composting process; that is, a decrease in moisture content prior to addition of POME. The final moisture content for the different compost sets were $58.0 \%$ (Set 1), $57.9 \%$ (Set 2), $60.2 \%$ (Set 3) and $55.3 \%$ (Set 4).

\section{Total Organic Content (TOC)}

The total organic carbon of the compost is measured to assess the rate of decomposition in the composting process. From Figure 4, it can be seen that the total organic carbon percentage of each set decreases slightly through composting.

The highest organic matter loss was exhibited by the pretreated EFB with POME which gave $63.76 \%$ organic matter loss. This was followed by the control (untreated EFB), pretreated EFB with POME plus inoculant and then untreated EFB with POME plus inoculant with organic matter loss of $55.44 \%, 36.81 \%$, and $32.43 \%$, respectively. Highest $\mathrm{OM}$ loss for

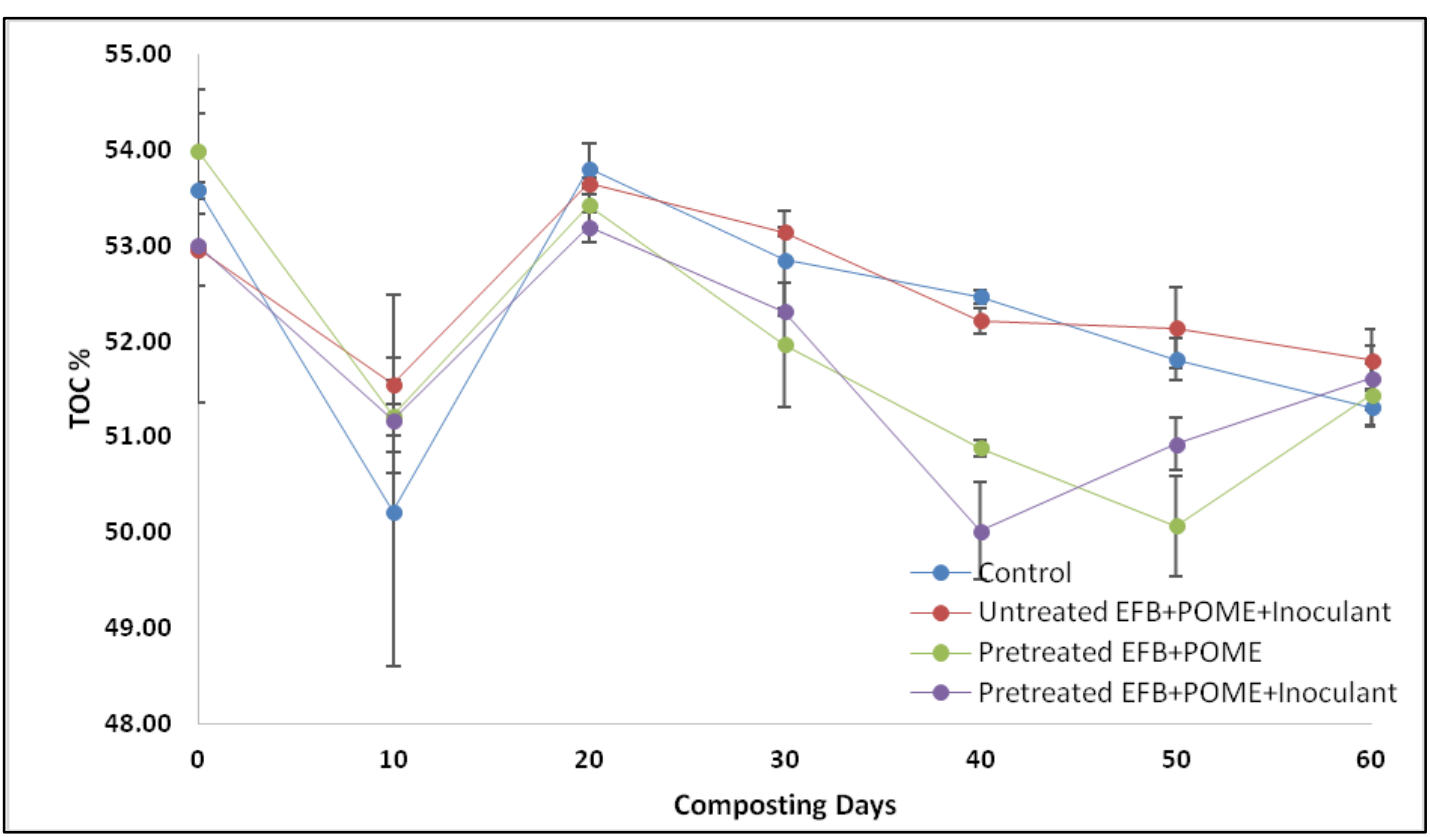

Fig. 3: Percentage of total organic carbon versus time during composting process for untreated and pretreated EFB under different conditions. EFB denotes Empty Fruit Bunch, POME: Palm Oil Mill Effluent. 
A.Y. Zahrim, I.K.T. Yee, E.S.C. Thian, S.Y. Heng, J. Janaun ,K.P. Chong, S.K. Haywood, V. Tan, T. 9 Asis, T.M.T.M.A Al-Mizi

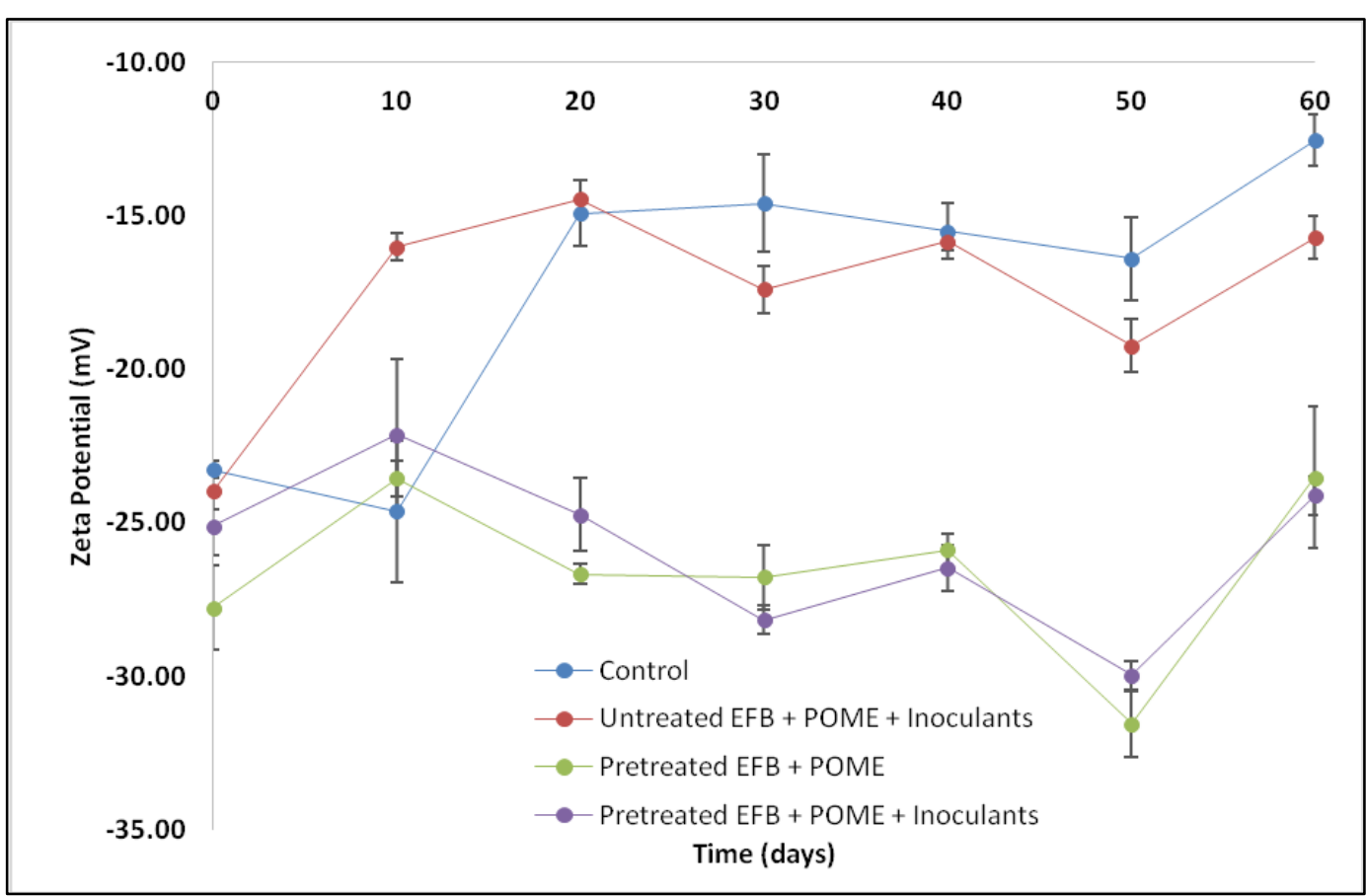

Fig. 4: Zeta Potential versus time during composting process for untreated and pretreated EFB under different conditions. EFB denotes Empty Fruit Bunch, POME: Palm Oil Mill Effluent

pretreated EFB is due to modifications in hemicellulose structure or the disruption of some linkages between hemicellulose, cellulose and lignin during the pretreatment (Diaz et al., 2015); this induces the indigenous microorganisms to utilize more organic matter. However, inoculation of Bacillus amyloliquefaciens D203 inhibiting the utilization of OM might be due to the antifungal properties of Bacillus amyloliquefaciens D203; this may have inhibited the growth of mesophilic fungi in the compost hence reducing the biodegradation rate (Alvarez et al., 2012, Ji et al., 2013).

The OM loss in this study (32\%-63\%) was comparable to the results reported by (Zhao et al., 2016), which had a maximum OM loss of $34 \%-54 \%$. On the otherand, the OM loss in composting of some agricultural waste was also reported to be in the range of $42 \%-58 \%$ (Kulcu and Yaldiz, 2004), which lies within the range found in this study. Moreover, (Petric and Mustafic, 2015) reported values of $37 \%-50 \%$ in composting of wheat straw with poultry manure.

\section{Zeta Potential}

The surface charge was measures using a zetasizer for compost (Figure 8). The zeta potential for Sets 1 and 2 show a lower initial and increase with composting time. However, the $\mathrm{NaOH}$ - microwave pretreatment might have led the particle surface to be dominated by the presence of carboxyl $(-\mathrm{COOH})$, carbocylate $(-\mathrm{COOH})$ and alcoholic groups (-OH) (Sun et al., 2002, Bellmann et al., 2004); this could cause the decrease of zeta potential value as the compost tends to become more hydrophilic (Zahrim et al., 2014, Bellmann et al., 2004, Zahrim et al., 2016). In addition, 
silica bodies might be removed during pretreatment. In Set 1 and 2, the concentration of silica in the solution increases and cause the deposition of silica onto the EFB surface whereas in Set 3 and $4, \mathrm{Na}^{+}$is absorbed on the EFB surface.

\section{Phytotoxicity}

The germination test has usually been used to evaluate the compost maturity and phytotoxicity of biowastes (Miaomiao et al., 2009). This index had been proven to be a more sensitive parameter to illuminate both low toxicity affecting root growth and high toxicity affecting germination (Zucconi et al., 1981). Figure 6 presents results of seed germination inhibition and root growth for the cabbage seeds, taken every 10 days during composting. The germination indices $(\mathrm{Gl})$ obtained for each set of compost demonstrated a trend of decreasing phytototxicity with composting time.

After the first month of composting, there is a significant increase in the germination index, especially on the $30^{\text {th }}$ day for all sets of compost; after the first month of composting this index (Gl) underwent a slight decline. As composting proceeded, Gl increased and reached $\sim 60$ (for both pretreated compost samples i.e. Sets $3 \& 4$ ) and $>80$ (for both untreated compost samples i.e. Sets $1 \& 2$ ) at the termination of composting. (Zucconi et al., 1981) reported that Gl's above $80 \%$ indicated the disappearance of phytotoxicity in compost, while $\mathrm{Gl}>50 \%$ indicated no detriment to olive plant growth (Tam and Tiquia, 1994, Zucconi et al., 1981).

In summary, high temperature microwave pretreatment causes the formation of complex refractory products and inhibitory digestion compounds that

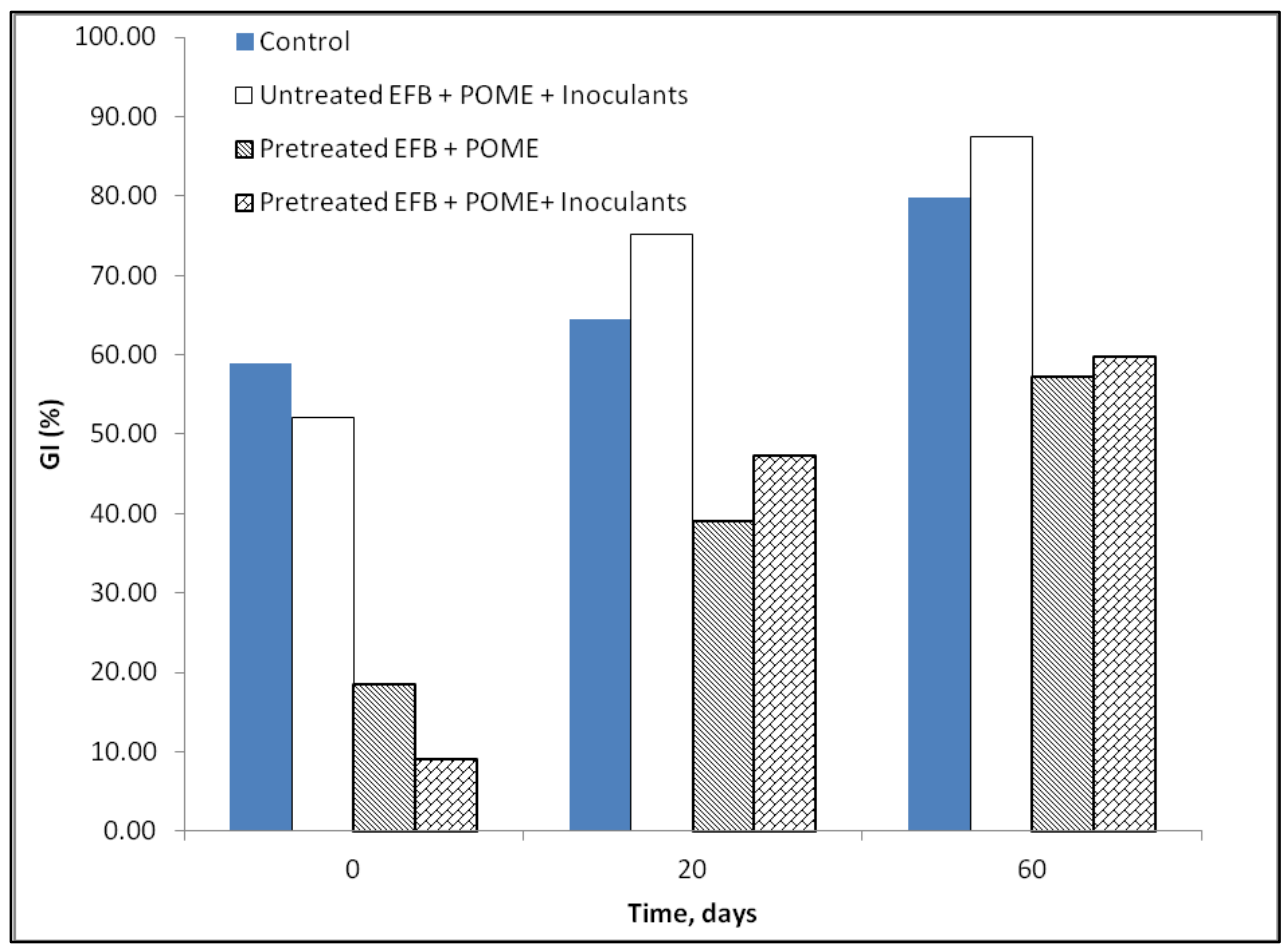

Fig. 6: Gl versus time during composting process for untreated and pretreated EFB under different conditions. EFB denotes Emptv Fruit Bunch, POME: Palm Oil Mill Effluent 
A.Y. Zahrim, I.K.T. Yee, E.S.C. Thian, S.Y. Heng, J. Janaun ,K.P. Chong, S.K. Haywood, V. Tan, T. 11 Asis, T.M.T.M.A Al-Mizi

affect the pretreated EFB composts. These show smaller $\mathrm{Gl}$ values as microwave pretreatment of biomass did not improve the digestion of waste when compared with untreated EFB compost (Shahriari et al., 2013). It was reported that the present of furan compounds produced from hydrothermal pretreatment inhibited the microbial activities of composting microorganism, thus delaying the start of degradation of organic matter in pretreated EFB composting (Nakasaki et al., 2015). For compost without inoculation, the compost was characterized by higher phytotoxicity, synonymous with results which show that inoculation composts have the lower phytotoxicity (Piotrowska-Cyplik et al., 2013). Interestingly, inoculant is found to increase the $\mathrm{Gl}$ for pretreated compost, which is supported by other research (Nakasaki et al., 2015). Phytotoxicity or poor plant response can result from several factors such as lack of oxygen due to high microbial activity, the accumulation of toxic compounds (organic acids), the immobilization of nitrogen with high C:N ratio, high ammonia concentration and the presence of heavy metals and mineral salts (Tiquia, 2010). These factors influence seed germination simultaneously and it is difficult to assess which parameter has the greatest influence. The immobilization of nitrogen at high C:N ratio and with high ammonia concentration contributes to compost phytotoxicity (Tiquia, 2010). A GI > 60 (the threshold limit for compost to show maturity) was reached as the composting time proceeded (Gaind, 2014). It is believed that composting strategies affected the speed of composting, time of maturation and disappearance of phytotoxicity (El Fels et al., 2014).

\section{CONCLUSIONS}

The effects of microwave pretreatment and inoculants on composting process in mesophilic condition were investigated. It was found that microwave-assisted $\mathrm{NaOH}$ pretreatment without inoculant could reduce the OM by about $15 \%$ more than without pretreatment. However, the pretreatment might produce phytotoxin that could inhibit seed growth. The inoculant in this study seems not to work well in the pretreated environment. Microwaveassisted $\mathrm{NaOH}$ pretreatment could enhance the composting process with the addition of suitable inoculants. In addition, microwave-assisted pretreatment without $\mathrm{NaOH}$ should also be investigated in the future. The inoculants enhance the composting process for the untreated EFB. The $\mathrm{pH}$ increased from 6.5 to 8.6 and the electrical conductivity increased up to a final acceptable value of $3863.33 \mu \mathrm{S} / \mathrm{cm}$. The germination index ( $\mathrm{Gl}$ ) increased from $57 \%$ to $87 \%$, which shows it is free from phytoxicity.

\section{ACKNOWLEDGEMENT}

The authors would like to thank Universiti Malaysia Sabah and British Council Newton Fund (Enhancing environmental resilience \& energy security by developing efficient novel methods for converting palm oil waste to biodiesel and fertilizer) for funding this project. 


\section{REFERENCES}

1. AHMAD, M. N., MOKHTAR, M. N., BAHARUDDIN, A. S., HOCK, L. S., ALI, S. R. A., ABDUL-AZIZ, S., RAHMAN, N. A. A. \& HASSAN, M. A. (2011) Changes in Physicochemical and Microbial Community During Co-composting of Oil Palm Frond with Palm Oil Mill Effluent Anaerobic Sludge. Bioresources, 6, 4762-4780.

2. AHMAD, M. N., MOKHTAR, M. N., BAHARUDDIN, A. S., HOCK, L. S., ALI, S. R. A., ABDUL-AZIZ, S., RAHMAN, N. A. A. \& HASSAN, M. A. (2011) Changes in Physicochemical and Microbial Community During Co-composting of Oil Palm Frond with Palm Oil Mill Effluent Anaerobic Sludge. Bioresources, 6, 4762-4780.

3. ALHAJI, M. H., SANAULLAH, K., LIM, S.F., KHAN, A., HIPOLITO, C. N., ABDULLAH, M. O., BHAWANI, S. A. \& JAMIL, T. (2016) Photocatalytic treatment technology for palm oil mill effluent (POME)- A review. Process Safety and Environmental Protection, 102, 673-686.

4. ALVAREZ, F., CASTRO, M., PRINCIPE, A., BORIOLI, G., FISCHER, S., MORI, G. \& JOFRE, E. (2012) The plant-associated Bacillus amyloliquefaciens strains MEP2 18 and ARP2 3 capable of producing the cyclic lipopeptides iturin or surfactin and fengycin are effective in biocontrol of sclerotinia stem rot disease. J Appl Microbiol., 112, 159-174.
5. BAHARUDDIN, A. S., KAZUNORI, N., ABD-AZIZ, S., TABATABAEI, M., RAHMAN, N. A. A., HASSAN, M. A., WAKISAKA, M., SAKAI, K. \& SHIRAI, Y. (2009) Characteristics and Microbial Succession in Co-composting of Oil Palm Empty Fruit Bunch and Partially Treated Palm Oil Mill Effluent.

6. BARI, M. N., ALAM, M. Z., MUYIBI, S. A., JAMAL, P. \& MANMUN, A. A. (2010) Effect of Particle Size on Production of Citric Acid from Oil Palm Empty Fruit Bunches as New Substrate by Wild Aspergillus niger. Journal of Applied Science, 10, 2648-2652.

7. BELLMANN, C., CASPARI, A., LOAN DOAN, T. T., MÄDER, E., LUXBACHER, T. \& KOHL, R. (2004) Electrokinetic Properties of Natural Fibres. International Electrokinetics Conference, June 15. Pittsburgh, PA.

8. BINOD, P., SATYANAGALAKSHMI, K., SINDHU, R., JANU, K. U., SUKUMARAN, R. K. \& PANDEY, A. (2012) Short duration microwave assisted pretreatment enhances the enzymatic saccharification and fermentable sugar yield from sugarcane bagasse. Renewable Energy, 37, 109-116.

9. BUKHARI, N. A., LOH, S. K., NASRIN, A. B., MOHAMMAD AZRI, S., MUZZAMMIL, N., DARYL, J. T., NORDIANA, M. S., LIM, W. S. \& CHOO, Y. M. (2014) Composting of Oil Palm Biomass - Current Status in Malaysia. National Seminar on Palm Oil Milling, Refining, Environment and Quality 
A.Y. Zahrim, I.K.T. Yee, E.S.C. Thian, S.Y. Heng, J. Janaun ,K.P. Chong, S.K. Haywood, V. Tan, T. 13 Asis, T.M.T.M.A Al-Mizi

(POMREQ). Pullman Hotel Kuching, Sarawak, Malaysian Palm Oil Board.

10. DIAZ, A. B., MORETTI, M. M. D. S., BEZERRA-BUSSOLI, C., CARREIRA NUNES, C. D. C., BLANDINO, A., DA SILVA, R. \& GOMES, E. (2015) Evaluation of microwave-assisted pretreatment of lignocellulosic biomass immersed in alkaline glycerol for fermentable sugars production. Bioresource Technology, 185, 316-323.

11. EL FELS, L., ZAMAMA, M., EL ASLI, A. \& HAFIDI, M. (2014) Assessment of biotransformation of organic matter during co-composting of sewage sludge-lignocelullosic waste by chemical, FTIR analyses, and phytotoxicity tests. International Biodeterioration \& Biodegradation, 87, 128-137.

12. GAIND, S. (2014) Effect of fungal consortium and animal manure amendments on phosphorus fractions of paddy-straw compost. International Biodeterioration \& Biodegradation, 94, 90-97.

13. GALLAWA, J. C. (2013) How to Check the Output Power of a Microwave Oven.

14. GAO, M., LI, B., YU, A., LIANG, F., YANG, L. \& SUN, Y. (2010) The effect of aeration rate on forced-aeration composting of chicken manure and sawdust. Bioresource Technology, 101, 1899-1903.

15. HOCK, L. S., BAHARUDDIN, A. S., AHMAD, M. N., SHAH, U. K. M., RAHMAN, N. A. A., ABD-AZIZ, S., HASSAN, M. A. \& SHIRAI, Y. (2009) Physicochemical Changes in Windrow
Co-composting Process of Oil Palm Mesocarp Fiber and Palm Oil Mill Effluent Anaerobic Sludge. Australian Journal of Basic and Applied Sciences, 3, 2809-2816.

16. JI, S. H., PAUL, N. C., DENG, J. X., KIM, Y. S., YUN, B. S. \& YU, S. H. (2013) Biocontrol Activity of Bacillus amyloliquefaciens CNU114001 against Fungal Plant Diseases. Mycobiology, 41, 234-242.

17. JINA, W., ZITIAN, F., XIAOLEI, Z. \& DI, P. (2009) Properties of Sodium Silicate Bonded Sand Hardened by Microwave Heating. Research \& Development, 6, $191-196$.

18. JUNG, Y. H., KIM, I. J., KIM, H. K. \& KIM, K. H. (2013) Dilute acid pretreatment of lignocellulose for whole slurry ethanol fermentation. Bioresource Technology, 132, 109-114.

19. KANANAM, W., SUKSAROJ, T. T. \& SUKSAROJ, C. (2011) Biochemical Changes during Oil Palm (Elaeis guineensis) Empty Fruit Bunches Composting with Decanter Sludge and Chicken Manure. ScienceAsia, 37, 17 23.

20. KAVITHA, B., JOTHIMANI, P. \& RAJANNAN, G. (2013) Empty fruit bunch-a potential organic manure for agriculture. International Journal of Science, Environment and Technology, 2, 930-937.

21. KULCU, R. \& YALDIZ, O. (2004) Determination of aeration rate and kinetics of composting some agricultural wastes. Bioresource Technology 93, 49-57. 
22. LIM, L. Y., BONG, C. P. C., CHUA, L. S. \& LEE, T. L. (2015) Physicochemical profile of microbial-assisted composting on empty fruit bunches of oil palm trees. Environ Sci Pollut Res, 22, 19814-19822.

23. LIN, C. (2008) A negative-pressure aeration system for composting food wastes. Bioresource Technology, 99, 7651-7656.

24. LISTER, T. \& RENSHAW, J. (1991) Understanding Chemistry for Advanced Level, Cheltenham, Stanley Thornes Ltd.

25. MIAOMIAO, H., WENHONG, L., XINQIANG, L., DONGLEI, W. \& GUANGMING, T. (2009) Effect of composting process on phytotoxicity and speciation of copper, zinc and lead in sewage sludge and swine manure. Waste Management, 29, 590-597.

26. MITTAL, A. (2002) Physical Chemistry, New Delhi, A.P.H. Publishing Corporation.

27. NAKASAKI, K., MIMOTO, H., TRAN, Q. N. M. \& OINUMA, A. (2015) Composting of food waste subjected to hydrothermal pretreatment and inoculated with Paecilomyces sp. FA13. Bioresource Technology, 180, 40-46.

28. OUATMANE, A., PROVENZANO, M. R., HAFIDI, M. \& SENSI, N. (2000) Compost Maturity Assessment Using Calorimetry, Spectroscopy and Chemical Analysis. Compost Sci. Utilis, 8, $124-134$.

29. PAN, I. \& SEN, S. K. (2013) Microbial and Physio-chemical Analysis of Composting process of Wheat Straw. Indian Journal of Biotechnology, 12, $120-128$.
30. PAREDES, C., ROIG, A., BERNAL, M. P., SANCHEZ-MONEDERO，M. A. \& CEGARRA， J. (2000) Evolution of Organic Matter and Nitrogen during Co-composting of Olive Mill Wastewater With Solid Organic Wastes. Biol Fertile Soils, 3, 222-227.

31. PETRIC, I. \& MUSTAFIC, N. (2015) Dynamic modeling the composting process of the mixture of poultry manure and wheat straw. Journal of Environmental Management, 161, 392401.

32. PHILIPSE, A. \& VRIJ, A. (2011) The Donnan Equilibrium: On the Thermodynamic Foundation of the Donnan Equation of State. Journal of Physics: Condensed matter, 23, 1-11.

33. PIOTROWSKA-CYPLIK, A., CHRZANOWSKI, Å. U., CYPLIK, P., DACH, J., OLEJNIK, A., STANINSKA, J., CZARNY, J., LEWICKI, A., MARECIK, R. \& POWIERSKA-CZARNY, J. (2013) Composting of oiled bleaching earth: Fatty acids degradation, phytotoxicity and mutagenicity changes. International Biodeterioration \& Biodegradation, 78, 49-57.

34. ROWELL, D. L. (1994) Soil science : methods and applications, Harlow, Essex, Addison Wesley Longman.

35. RUIZ-DUENAS, F. J. \& MARTINEZ, A. T. (2009) Microbial degradation of lignin: How a bulky recalcitrant polymer is efficiently recycled in nature and how we can take advantage of this. Microbial Biotechnology, 2, 164-177.

36. SHAHRIARI, H., WARITH, M., HAMODA, M. \& KENNEDY, K. (2013) Evaluation of 
A.Y. Zahrim, I.K.T. Yee, E.S.C. Thian, S.Y. Heng, J. Janaun ,K.P. Chong, S.K. Haywood, V. Tan, T. 15 Asis, T.M.T.M.A Al-Mizi

single vs. staged mesophilic anaerobic digestion of kitchen waste with and without microwave pretreatment. Journal of Environmental Management, $125,74-84$.

37. STENIUS, P. (2011) Surface Chemistry and Charge of Cellulosic Fibres. Stockholm, PS Interfaces.

38. SUN, R., LU, Q. \& SUN, X. F. (2002) Characterization of hemicelluloses and lignin released in two-stage organosolv and alkaline peroxide treatments from Populus euphratica. Cellulose Chemistry and Technology, 36, 243263.

39. TAM, N. F. Y. \& TIQUIA, S. (1994) Assessing toxicity of spent pig litter using a seed germination technique. Resources, Conservation and Recycling, 11, 261-274.

40. TIQUIA, S. (2010) Reduction of compost phytotoxicity during the process of decomposition. Chemosphere, 79, 506512.

41. TUVAL, T. \& GEDANKEN, A. (2007) A microwave-assisted polyol method for the deposition of silver nanoparticles on silica spheres. Nanotechnology, 18, $1-7$.

42. VAKILI, M., HAQUE, A. A. M., HOSSEINI, S. M. \& SALAMATINIA, B. (2012) Evaluation of Maturation and Stanility Some Indexes of Mixed Palm Oil Biowaste Composting Process and Poultry Litter. World Applied Sciences Journal 19, 234 - 240.

43. YANG, L., ZHANG, S., CHEN, Z., WEN, Q. \& WANG, Y. (2016) Maturity and security assessment of pilot-scale aerobic co-composting of penicillin fermentation dregs (PFDs) with sewage sludge. Bioresource Technology, 204, 185-191.

44. ZAHRIM, A. Y. \& ASIS, T. (2010) Production of Non Shredded Empty Fruit Bunch Semi-Compost. The Institution of Engineers, Malaysia, 71.

45. ZAHRIM, A. Y., ASIS, T., HASHIM, M. A., AL-MIZI, T. M. T. M. A. \& RAVINDRA, P. (2015) A review on the empty fruit bunch composting: Life cycle analysis and the effect of amendment(s). IN RAVINDRA, P. (Ed.) Advances in Bioprocess Technology. Springer.

46. ZAHRIM, A. Y., LEONG, P. S., AYISAH, S. R., JANAUN, J., CHONG, K. P., COOKE, F. M. \& HAYWOOD, S. K. (2016) Composting paper and grass clippings with anaerobically treated palm oil mill effluent. Int J Recycl Org Waste Agricult, In Press.

47. ZAHRIM, A. Y., NASIMAH, A. \& HILAL, N. (2014) Pollutants analysis during conventional palm oil mill effluent (POME) ponding system and decolourisation of anaerobically treated POME via calcium lactatepolyacrylamide. Journal of Water Process Engineering, 4, 159-165.

48. ZAHRIM, A. Y., RAKMI, A. R. \& KALIL, M. S. (2007) Sludge Composting: A casr study on palm oil mill sludge (POms). AJChE, 7, 102-107.

49. ZAINUDIN, M. H. M., HASSAN, M. A., SHAH, U. K. M., ABDULLAH, N., TOKURA, M., YASUEDA, H., SHIRAI, Y., SAKAI, K. \& BAHARUDDIN, A. S. (2014) Bacterial Community Structure and Biochemical Changes Associated With Composting of Lignocellulosic Oil Palm Empty Fruit Bunch BioResources, 9, 316 - 335. 
50. ZAINUDIN, M. H. M., HASSAN, M. A., TOKURA, M. \& SHIRAI, Y. (2013) Indigenous Cellulolytic and Hemicellulolytic Bacteria Enhanced Rapid Co-composting of Lignocellulose Oil Palm Empty Fruit Bunch with Palm Oil Mill Effluent Anaerobic Sludge. Bioresource Technology, 147, 632-635.

51. ZHAO, X. L., LI, B. Q., NI, J. P. \& XIE, D. T.
(2016) Effect of four crop straws on transformation of organic matter during sewage sludge composting. Journal of Integrative Agriculture, 15, 232-240.

52. ZUCCONI, F., PERA, A., FORTE, M. \& DE BERTOLDI, M. (1981) Evaluating toxicity of immature compost. BioCycle (USA). 